\title{
Prevalence of Hepatitis D Virus Infection and Associated Factors Among HBsAg-Positive Patients in Birjand, Iran, 2012 - 2014
}

\author{
Gholamreza Sharifzadeh, ${ }^{1}$ Mohammad Hasan Namaei, ${ }^{1}$ Azadeh Ebrahimzadeh, ${ }^{1}$ Zohreh Azarkar, \\ Mohammad Fereidouni, ${ }^{2}$ Bita Bijari, ${ }^{1}$ Davod Javanmard, ${ }^{1}$ Mehdi Karamian, ${ }^{1}$ Marjan Farzad, ${ }^{1}$ and \\ Masood Ziaee ${ }^{1, *}$ \\ ${ }^{1}$ Infectious Diseases Research Center, Birjand University of Medical Sciences, Birjand, Iran \\ ${ }^{2}$ Cellular and Molecular Research Center, Birjand University of Medical Sciences, Birjand, Iran \\ "Corresponding author: Masood Ziaee, Infectious Diseases Research Center, Birjand University of Medical Sciences, Birjand, Iran. Tel: +98-9151613942, Fax: +98-5632433004, \\ E-mail:dr.m.ziaee@gmail.com
}

Received 2017 January 01; Revised 2017 February 26; Accepted 2017 March 13.

\begin{abstract}
Background: It is estimated that about $5 \%$ of hepatitis B surface antigen (HBsAg) carriers are infected with hepatitis D virus (HDV) worldwide. Moreover, dual infection with hepatitis B virus (HBV) / HDV causes more severe diseases and leads to a higher risk of mortality.

Objectives: This study was performed to determine the prevalence of HDV infection and identify HDV-associated factors among HBsAg-positive patients in Birjand, South Khorasan province, Iran.

Methods: This descriptive, cross sectional study was conducted on 5235 participants in line with a previous study on the seroprevalence of HBV in South of Khorasan. HDV was assessed through evaluating the blood serum of diagnosed HBsAg-positive patients (85 cases) by ELISA test. For statistical analysis, descriptive statistics were calculated, using SPSS version 22.

Results: In this study, the mean age of HBsAg-positive patients was $45.1 \pm 12.9$ years (minimum, 22 years; maximum, 70 years). In total, 1 out of 85 cases was positive for HDV virus. The prevalence of HDV infection among HBsAg-positive patients was 1.2\% (95\% CI, -1.2 to 3.5$)$.

Conclusions: The low prevalence of HDV infection in South of Khorasan was remarkable, considering the great area of this province, use of a comprehensive and inclusive sampling strategy, and mutual borders with Afghanistan.
\end{abstract}

Keywords: Hepatitis B, Hepatitis D, Prevalence, Iran

\section{Background}

Today, hepatitis B virus (HBV) is one of the most important health problems worldwide. HBV infection is the most common cause of chronic infection in humans and can lead to cirrhosis, hepatocellular carcinoma, and death due to liver failure (1). Hepatitis delta virus (HDV) is a defective RNA virus, which is only able to replicate and cause infection in HBV-infected patients, thereby resulting in a coinfection (2,3). In addition, dual infection with HBV/HDV causes more severe diseases and leads to a higher risk of mortality.

In a previous study by Roshandel et al., anti-HDV antibody was detected in 8 (5.8\%) hepatitis B surface antigen (HBsAg)-positive patients in Golestan province, Iran; however, demographic factors, such as age, place of residence, and marital status, had no significant relationship with HDV seropositivity (4). Moreover, in other previous studies, the prevalence of HDV infection was estimated at $3.5 \%$ in Isfahan (5), 7.6\% in Tabriz (6), and 17\% in Zahedan (7) among
anti-HBe-positive patients.

The majority of previous studies suggest that most HDV infections are acquired through parenteral and sexual routes. Therefore, patients undergoing hemodialysis and those infected with HIV are at risk of HDV infection (8). The interfamilial transmission of infection is also an important concern for patients and their families, as well as health service providers and policymakers (9). Since $\mathrm{HDV}$ virus intensifies acute and chronic $\mathrm{HBV}$ infection, it is necessary to determine its prevalence in the region. Also, health authorities should be aware of the risk of disease in patients and develop strategies for disease prevention and treatment.

\section{Objectives}

The present study was performed to determine the prevalence of HDV and the associated factors among HBsAg-positive patients in Birjand, Iran. 


\section{Methods}

\subsection{Patients and Setting}

This descriptive, cross sectional study was conducted in line with a previous study on the seroprevalence and risk factors for HBV in South of Khorasan (10). In order to determine the prevalence of HDV infection in Birjand, we used the blood serum of HBsAg-positive patients, who were evaluated in the aforementioned study on the seroprevalence and risk factors for $\mathrm{HBV}$ in an adult population in South of Khorasan (2014). In the mentioned study, sampling was carried out systematically among 5235 individuals older than 15 years (range, 15 - 75 years) in 2014.

\subsection{HDV Identification Method}

Anti-HDV was assessed by ELISA test (BioVendor, Germany) in the blood serum (stored at $-70^{\circ} \mathrm{C}$ ) of $85 \mathrm{HBsAg}$ positive patients. Demographic characteristics and risk factors for hepatitis, such as blood transfusion, surgery, cupping, narcotic abuse, infected family members, and close encounters, were extracted from a questionnaire, which was completed by the patients.

\subsection{Ethical Considerations}

This study was conducted after obtaining approval from the university ethics committee (N.1394.383) by disclosing the research methods and objectives and gathering written consent forms from all the participants.

\subsection{Statistical Analysis}

Descriptive statistics were calculated for data analysis, using SPSS version 22.

\section{Results}

In the present study, the mean age of HBsAg-positive patients was $45.1 \pm 12.9$ years (minimum, 22 years; maximum, 70 years). In total, 33 (38.8\%) and 52 (61.2\%) subjects were female and male, respectively. Based on the findings, 1 out of 85 patients was positive for HDV infection. The prevalence of HDV infection among HBsAg-positive patients was $1.2 \%$ (95\% CI, -1.2 to 3.5 ).

The anti-HDV-positive patient was a married 55-yearold woman with primary education and history of HBV infection, cupping, surgery, hospitalization, and endoscopy; she also had infected family members. However, no history of vaccination, smoking, alcohol abuse, or blood transfusion was found.

\section{Discussion}

The results of the present study showed that among 85 HBV-positive patients, only 1 case was positive for HDV infection. Therefore, the prevalence of HDV infection among HBsAg-positive patients was 1.2\% (95\% CI, -1.2 to 3.5). Evidence from different parts of the country has revealed the disparate prevalence rates of HDV (Table 1). In the present study, comparison of the prevalence of HDV in terms of age, sex, and other risk factors could not be performed, as only 1 anti-HDV-positive patient was detected.

Table 1. Prevalence of Hepatitis D Virus (HDV) Infection in Patients with Hepatitis B Virus (HBV) in Iranian Studies

\begin{tabular}{|c|c|c|}
\hline Author(s) & City & Prevalence of HDV \\
\hline Ghadir et al., 2012 (11) & Qom (Center of Iran) & $2 \%$ \\
\hline Ataei et al., 2011 (5) & Isfahan (Center of Iran) & $2.9 \%$ \\
\hline $\begin{array}{l}\text { Gholamrezaei et al., } \\
2007(12)\end{array}$ & $\begin{array}{l}\text { Golestan (Northeast of } \\
\text { Iran) }\end{array}$ & $5.8 \%$ \\
\hline Ziaee et al., 2013 (13) & $\begin{array}{l}\text { Birjand (South of } \\
\text { Khorasan) }\end{array}$ & $3.1 \%$ \\
\hline Somi et al., 2009 (14) & $\begin{array}{l}\text { Tabriz (Northwest of } \\
\text { Iran) and Tehran (capital } \\
\text { of Iran) }\end{array}$ & $9.3 \%$ \\
\hline Alizadeh et al., 2010 (15) & Hamadan (West of Iran) & $17.3 \%$ \\
\hline Amini et al., 2011 (16) & Iran & $6.61 \%$ \\
\hline Khazaee et al., 2016 (17) & $\begin{array}{l}\text { Birjand (South of } \\
\text { Khorasan) }\end{array}$ & $3.3 \%$ \\
\hline
\end{tabular}

The results of the current study revealed the lowest prevalence of HDV in Iran. Consistent with the current results, in the neighboring province (Khorasan Razavi), no anti-HDV-positive cases were identified among 3198 normal subjects, including $34 \mathrm{HBsAg}$-positive patients (18). Moreover, a study in Tabriz, Iran reported that risk of HDV significantly increases after 40 years, while no significant difference was found between men and women (14). These results are in line with the present findings, as the only anti-HDV-positive case in our study was 55 years old.

In contrast, situated in the Middle East, Iran has a high prevalence of HDV, and therefore, screening, disease prevention, and public health training need to be highlighted. These measures are even more important in some parts of the country where there has been a significant increase in the rate of HDV infection in the past decades (15). In Pakistan and Tajikistan, the prevalence of HDV has been reported to be high (19). In fact, the prevalence of HDV infection in different parts of Pakistan ranges between 16.6\% and $88.8 \%$ (19). Additionally, HDV infection is an acute medical problem in Southeast of Turkey and is relatively important in Eastern Europe (19). 
In conclusion, the low prevalence of HDV infection in South of Khorasan was interesting, considering the great area of this province, use of a comprehensive and inclusive sampling strategy, and mutual borders with Afghanistan. Previous studies around Iran have reported variable rates of HDV prevalence, which might be affected by various factors, such as sampling source and strategy, socioeconomic level of the population, and geographical region. The low prevalence reported in the current study might be attributed to the low admission rate of HDV-positive cases in this region, as well as the health level and sociocultural status of the population. Nevertheless, further investigations are required to determine the genotypic distribution and analyze the situation from a molecular perspective.

\section{Acknowledgments}

We would like to thank all the contributors and personnel of infectious diseases research center of Birjand University of Medical Sciences.

\section{Footnotes}

Authors' Contribution: All the authors contributed to the research design, data collection, and writing of the final manuscript.

Funding/Support: This study was financially supported by the infectious diseases research center of Birjand University of Medical Sciences.

\section{References}

1. Jabbari AR, Fattahi E, Alavian SM, Hosseini SM. Determination of hepatitis b frequency among family members of hbsag+ in military and non-military persons. J Military Med. 1383;6(2):99-104.

2. Knipe D. Fields Virology. 1. fourth ed. USA: Wolterskluwer Company; 2000. pp. 3037-48.

3. Modahl LE, Lai MM. Hepatitis delta virus: the molecular basis of laboratory diagnosis. Crit Rev Clin Lab Sci. 2000;37(1):45-92. doi: 10.1080/10408360091174178. [PubMed: 10737440].

4. Roshandel G, Semnani S, Abdolahi N, Besharat S, Keshtkar AA, Joshaqani $\mathrm{H}$, et al. Prevalence of hepatitis D virus infection in hepatitis B surface antigen-positive subjects in Golestan province, northeast Iran. J Microbiol Immunol Infect. 2008;41(3):227-30. [PubMed: 18629418].

5. Ataei B, Yazdani MR, Kalantari H, Yaran M, Nokhodian Z, Javadi AA, et al. Hepatitis D virus infection in Isfahan, central Iran: Prevalence and risk factors among chronic HBV infection cases. Hepat Mon. 2011;11(4):269-72. [PubMed: 22706272].
6. Torabi S, Ebrahimpour S, Maljaei S, Naghili B. Seroepidemiological studies of Hepatitis Delta (HDV) in HBsAg positive individuals in Tabriz. 2003

7. Bakhshipour A, Mashhadi M, Mohammadi M, Nezam SK. Seroprevalence and risk factors of hepatitis delta virus in chronic hepatitis $B$ virus infection in Zahedan. Acta Med Iran. 2013;51(4):260-4. [PubMed: 23690107].

8. Aghasadeghi MR, Mohraz M, Bahramali G, Aghakhani A, Banifazl $M$, Foroughi $M$, et al. Frequency and Genotype of Hepatitis D Virus Infection in Patients Infected with HIV and Those Undergoing Hemodialysis. Hepat Mon. 2013;13(5):ee7481. doi: 10.5812/hepatmon.7481. [PubMed: 23914228].

9. Pournik O, Alavian SM, Ghalichi L, Hajibeigi B, Razavi AR, Eslami $S$. Lower intrafamilial transmission rate of hepatitis $B$ in patients with hepatitis d coinfection: a data-mining approach. Hepat Mon. 2013;13(5):ee7652. doi: 10.5812/hepatmon.7652. [PubMed: 23922559].

10. Ziaee M, Ebrahimzadeh A, Azarkar Z, Namaei MH, Saburi A, Fereidouni M, et al. Seroprevalence and Risk Factors for Hepatitis B in an Adult Population: The First Report from Birjand, South Khorasan, Iran. Hepat Mon. 2016;16(9):ee36452. doi: 10.5812/hepatmon.36452. [PubMed: 27822260].

11. Ghadir MR, Belbasi M, Heidari A, Sarkeshikian SS, Kabiri A, Ghanooni $\mathrm{AH}$, et al. Prevalence of hepatitis d virus infection among hepatitis $\mathrm{B}$ virus infected patients in qom province, center of iran. Hepat Mon. 2012;12(3):205-8. doi: 10.5812/hepatmon.847. [PubMed: 22550529].

12. Gholamreza R, Shahryar S, Abbasali K, Hamidreza J, Abdolvahab M, Khodaberdi K, et al. Seroprevalence of hepatitis B virus and its coinfection with hepatitis D virus and hepatitis $C$ virus in Iranian adult population. Indian J Med Sci. 2007;61(5):263-8. [PubMed: 17478956].

13. Ziaee M, Azarkar G. Prevalence of hepatitis d virus infection among patients with chronic hepatitis B attending birjand hepatitis clinic (East of iran) in 2012. Hepat Mon. 2013;13(8):ee11168. doi: 10.5812/hepatmon.11168. [PubMed: 24171009].

14. Somi MH, Farhang S, Miri SM, Pouri AA, Mjidi G, Alavian SM. The frequency of hepatitis $D$ virus in patients with hepatitis $B$ in Iran: an increasing rate?. Trop Doct. 2009;39(3):154-6. doi: 10.1258/td.2009.080365. [PubMed: 19535751].

15. Mohammad Alizadeh AH, Ranjbar M, Tehrani AS, Keramat F, Mamani M, Rezazadeh M, et al. Seroprevalence of hepatitis D virus and its risk factors in the west of Iran. J Microbiol Immunol Infect. 2010;43(6):51923. doi: 10.1016/S1684-1182(10)60080-1. [PubMed: 21195980].

16. Amini N, Alavian SM, Kabir A, Saiedi Hosseini SY, Aalaei Andabili SH. Clinical Features and Seroepidemiology of Anti-HDV Antibody in patients With Chronic Hepatitis B Virus Infection in Iran: A Meta-Analysis. Hepat Mon. 2011;11(12):960-7. doi: 10.5812/kowsar.1735143X.805. [PubMed: 22368679].

17. Khazaee T, Ebrahimzadeh A, Moghaddam E, Ghafori M. assessment of prevalence and determin infections of Hepatitis C and Hepatitis D in patients with chronic Hepatitis B. GOVARESH. 2016;20(4):230-6.

18. Nomanee H, Rostami S, Taghi Shakeri M, Meshkat Z. Evidence of Hepatitis D Virus Infection in HBsAg Positive Subjects of Mashhad, North-East of Iran. Jundishapur J Microbiol. 2015;8(10):ee7214. doi: 10.5812/jjm.7214. [PubMed: 26568806].

19. Rizzetto M, Ciancio A. Epidemiology of hepatitis D. Semin Liver Dis. 2012;32(3):211-9. doi: 10.1055/s-0032-1323626. [PubMed: 22932969]. 